\title{
Animal Welfare, Health and the Fight against Climate Change: One Solution for Global Objectives
}

\author{
Giancarlo Bozzo ${ }^{1}$ (), Marialaura Corrente ${ }^{1}$, Giovanni Testa ${ }^{2}$, Gaia Casalino ${ }^{1}$, Michela Maria Dimuccio ${ }^{1}$, \\ Elena Circella ${ }^{1}{ }^{1}$, Nazario Brescia ${ }^{3}$, Roberta Barrasso ${ }^{1}\left[{ }^{\mathbb{D}}\right.$ and Francesco Emanuele Celentano ${ }^{3, *}$ \\ 1 Department of Veterinary Medicine, University of Bari Aldo Moro, Strada Provinciale per Casamassima, \\ km 3, 70010 Valenzano, Italy; giancarlo.bozzo@uniba.it (G.B.); marialaura.corrente@uniba.it (M.C.); \\ gaia.casalino@uniba.it (G.C.); michy.dimuccio@gmail.com (M.M.D.); elena.circella@uniba.it (E.C.); \\ roberta.barrasso@uniba.it (R.B.) \\ 2 Postgraduate School in Inspection of Food of Animal Origin, Veterinary Medicine, University of Bari, \\ Strada Provinciale per Casamassima km 3, 70010 Valenzano, Italy; giovanni.testa@outlook.com \\ 3 Department of Law, University of Bari Aldo Moro, Piazza Umberto I, 70121 Bari, Italy; \\ nazario.brescia@uniba.it \\ * Correspondence: francesco.celentano@uniba.it; Tel.: +39-080-5717767
}

\section{check for} updates

Citation: Bozzo, G.; Corrente, M.; Testa, G.; Casalino, G.; Dimuccio, M.M.; Circella, E.; Brescia, N.; Barrasso, R.; Celentano, F.E. Animal Welfare, Health and the Fight against Climate Change: One Solution for Global Objectives. Agriculture 2021, 11, 1248. https://doi.org/10.3390/ agriculture 11121248

Academic Editor:

Claudia Arcidiacono

Received: 17 November 2021

Accepted: 7 December 2021

Published: 9 December 2021

Publisher's Note: MDPI stays neutral with regard to jurisdictional claims in published maps and institutional affiliations.

Copyright: (c) 2021 by the authors. Licensee MDPI, Basel, Switzerland. This article is an open access article distributed under the terms and conditions of the Creative Commons Attribution (CC BY) license (https:/ / creativecommons.org/licenses/by/ $4.0 /)$.

\begin{abstract}
Climate change is internationally recognized as a source of concern by governments, scientists and public opinion. In this context, the need to find concrete solutions becomes increasingly urgent. Numerous economic sectors contribute to alteration of climate, especially livestock and, more generally, food production-related activities. For this reason, animal welfare policies, the complex of norms and regulations adopted by single Member States and the European Union in the field of meat production, could be a useful instrument in the climate transition invoked by policy makers and scientists. The aim of this paper was to analyze the current system of animal welfare from a legal and veterinary perspective, and to demonstrate how important and useful, it could be in the fight against climate change; at least if correctly implemented and applied.
\end{abstract}

Keywords: animal welfare; health; antibiotics; climate change

\section{Introduction}

In 1988, with the adoption of resolution $43 / 54$ by the United Nations General Assembly, the international community stated its awareness that some human activities could affect the global climate. Since then, more than 30 years on, nothing has changed in terms of the effectiveness of international norms in countering climate change [1].

This international problem is becoming increasingly urgent considering the constant growth in the world population. According to the United Nations, this is set to reach about 8.6 billion in 2030 and 9.8 billion in 2050 .

Population growth, urbanization, and increased incomes in developing countries are the main drivers of the higher demand for livestock products [2]. Indeed, the livestock sector requires significant amounts of natural resources and is responsible for about $14.5 \%$ of total anthropogenic greenhouse gas emissions [3]. Moreover, in intensive farming regimes, the use of drugs such as antimicrobials is widespread. Consequently, the application of a new, and more sustainable, method of farming becomes paramount. Animal welfare seems to be the best solution to help innovate the livestock sector and, above all, to safeguard human and animal health without neglecting environmental protection; any mitigation of emissions from livestock must be based on high animal welfare standards, so as to enhance the potential for reducing emissions [4]. The aim of this paper was to illustrate the current context of climate change and global warming law in the European Union (EU), in the farming sector. Furthermore, the authors intended to analyze how animal welfare could improve human health, via food production. 


\section{Climate Change and Farming: International Regulation and Perspective}

The international legal standards adopted over the last 30 years to contrast climate change are mainly based on a number of different conventions. The first, adopted in 1992, is the United Nations Framework Convention on Climate Change (UNFCCC). It provides general principles on climate regulation and, above all, instituted the UN Conference of Parties (CoP) that serves as an international forum on climate policy. During the annual Conference meetings, two further legal instruments have been negotiated and adopted that make up the international legal framework on climate change: the Kyoto Protocol, in 1997, and then the 2015 Paris Agreement on Climate Change [1]. New livestock, part of a complex web of different activities related to the production of food of animal origin, is mainly regulated at national level. Each State applies its own norms, whereas the impact of farming in climate terms is global. It has become paramount to adopt a common method of farming which can facilitate a new, and more sustainable, approach towards animal use in food production.

Many international organizations are working on this objective, including the World Organization for Animal Health (OIE), the United Nations for Food and Agriculture Organization (FAO) and, at European level, the EU. Each one cites animal welfare as an indispensable method for modernizing livestock activities. The main difference between these organizations is the concrete impact of their activities. Unlike the EU, the OIE and FAO do not have binding powers, and can therefore only advise governments, promote studies and suggest guidelines, whereas the EU makes binding decisions in the field of agriculture, which includes livestock [5]. Indeed, Article 4 of the Treaty on the Functioning of the EU [6] states that the Organizations share power over agricultural regulations with Member States. The international climate law system is basically designed to reduce pollution. Animal livestock is one of the most polluting activities on Earth and Animal welfare policies are becoming increasingly crucial in the fight against carbon emissions [7].

\section{Livestock Supply Chains: Impact on Animal Welfare and Environmental Sustainability}

Through its Green Deal and Farm to Fork strategies, the EU has defined some specific objectives for the livestock sector, in particular reducing its environmental impact, improving animal welfare and reducing the use of veterinary drugs, with particular reference to antimicrobials. As part of the European Green Deal, the EU has set itself the key objective of achieving climate neutrality by 2050 [8]. This will require a significant reduction in current levels of greenhouse gas emissions over the coming decades. As an intermediate step towards climate neutrality, the EU has made a more ambitious climate pledge to reduce emissions by at least $55 \%$ by 2030 (Fit for 55 project). The new Common Agricultural Policy (CAP) itself, recalibrated, includes these issues and inserts them into a fundamental concept of One-Health, meaning that the health of the planet derives from an overall balance between human, animal, and plant health [8].

The fundamental role of agriculture and livestock is to meet the demand for food, and the recent COVID-19 pandemic has underlined how important it is to have a robust supply chain $[9,10]$. Furthermore, the income factor is central to businesses, which must be helped to become more efficient and competitive by guaranteeing that they can earn the income necessary to move forward and to adopt modern animal welfare policies, given that the global consumption of food of animal origin is on the rise [11], and is putting increasing pressure on ecosystems [12].

The 2009 Treaty of Lisbon explicitly recognizes that animals are sentient beings and that the EU and its Member States have an ethical responsibility to prevent mistreatment, pain and suffering [13]. This is the most significant response to the growing demand from European citizens to recognize animals' dignity, so as to distance animals from their historical legal position of being mere res [14].

This research field is an important opportunity for growth, with a view to continuous improvements in animal welfare, but also above all from an economic point of view, as it has now been established that where welfare improves, so too does the quality of produc- 
tion [15]. Designing protected environments around the needs of species and improving management practices thanks to responsible action from all operators along the food chain $[16,17]$ is all to the advantage of productivity, as it drastically reduces diseases, health interventions, use of drugs, mortality, and losses on farms and in slaughterhouses [18]. Equally important is winning over consumer confidence, as their choices are now increasingly rewarding producers who adopt virtuous and sustainable management models. Indeed, supply chain operators know that ensuring the welfare of animals is essential for good production and therefore for adequately remunerated efforts, so compliance with the regulations has to be a priority throughout the animals' lives, from breeding to fattening to the slaughterhouse, including transport.

Supply chains are tools capable of building value and transforming a territory at a social and economic level. They are vectors of innovation, in particular as regards sustainable practices in production, distribution and consumption. Whereas it is right to evaluate the impact that products of animal origin can have on the environment [19], on the other hand the modern concept of circular economy becomes key, in which waste is turned into a resource and a great opportunity for sustainable growth by reducing the consumption of natural resources and the development and implementation of technologies for material recycling and energy recovery. From cattle and pig farming, for example, not only are meat, milk and leather obtained, but also numerous other co-products destined for various sectors: from the feed sector through the proceeds of raw material to be used for pet food [20], to pharmaceuticals, with pericardial tissue being used for heart valves or gelatin used to make capsules for drugs [21]. Moreover, the cosmetic sector, in which fats are used for making soaps; the human food sector, which uses calf abomasum to extract enzymatic complexes for making natural rennet for cheese [22]; and last but not least agriculture, where rumen content and manure are used as raw materials to feed anaerobic digestion plants [23] from which digestate is obtained, to fertilize the soil or produce soil improvers [24], and biogas [25], which, if refined, becomes biomethane, with qualities similar to those of natural gas [26]. These substances are fed into the network and used for heating, cooking and automotive applications. The biogas obtained from farm waste can therefore be a precious ally of road transport and the energy sector in emancipating us from oil and in the fight against climate change, helping reduce carbon dioxide $\left(\mathrm{CO}_{2}\right)$ emissions as shown in a study carried out in the province of Cremona concerning the optimization of biogas production in one of the Italian areas most intensively dedicated to animal husbandry [27].

A further element pushing towards better animal welfare and which, at the same time, has a positive impact on the environment, concerns feeding animals a sustainable diet that includes the self-production of raw materials used in the rations and the reuse of former food products for human use, while still guaranteeing nutritional efficiency and at the same time high food safety. Self-production reduces the need to import raw materials and feed from territories that unconditionally exploit their natural resources, applying unsustainable practices such as deforestation; for example, almost all imported soybeans come from the Americas and, in some cases-in order to make room for agricultural land to be used for its cultivation-whole swathes of tropical forest have been eliminated, thus causing enormous damage to biodiversity and the environment in general [28]. By adopting a policy of self-sufficiency, we would increasingly move towards a process of so-called "carbon neutrality", which needs to characterize the agricultural and animal production processes, as other production cycles [29], thus also helping to reduce the abandonment of farmland. Faced with this scenario, the agri-food sector is evolving rapidly, seeking to do everything possible to concretely respond to the requirements of increasingly demanding consumers, proposing certifications and traceability systems which offer purchasers all the information they need to understand the product's history in detail; examples include the Round Table on Responsible Soy Association (RTRS) certification concerning the soy supply chain, or the project of the Global Feed LCA Institute (GFLI) which was created to provide tools to support a correct assessment of the impact of feed production. Launched in 2015 in 
the United States, the project is promoted by several international associations, including FEFAC, AFIA, ANAC and IFIF (i.e., the associations/federations of feed producers in Europe, America, Canada and the international federation), as well as by a plethora of national associations and international companies. Commission Regulation (EU) No 68/2013 of 16 January 2013 concerning the Catalogue of feed materials introduces the definition of former foodstuffs or ex-food, i.e., food products originally designed for human use compliant with the requirements of European regulations but which, for various reasons of an aesthetic or logistical nature, do not fall within the cycle of human nutrition and can be reused for the production of zootechnical feeds, identifying them as an opportunity in the zootechnical supply chains that are seeking to be defined as sustainable [30]. The new raw materials used are obtained from bakery products (bread, biscuits, rusks), confectionery products (chocolate, candies, snacks, etc.), products of cereal processing (puffed, extruded cereals, and cereal by-products) and dairy products. The sheer variety of ingredients and the high technology involved make it possible to prepare safe and sustainable food (simple and compound feeds) for animal husbandry [31]. Through a robust traceability system and constant product and process controls, reliable and specific formulations can be guaranteed for various types of animals, from poultry to swine to bovines (thus, for example, guaranteeing more stable ruminal fermentations and a greater appetite, a clear and unequivocal sign of good animal welfare), differentiating the composition to meet the specific needs of each phase of the animal's life. Proper nutrition translates into a more prudent use of veterinary drugs and less metabolic waste; reducing the number of unproductive animals lowers the production of climate-altering gases such as enteric methane $\left(\mathrm{CH}_{4}\right)$ [32], one of the best-known issues related to animal husbandry [33].

\section{Animal Welfare as an Instrument for Evolution in Farming Activities}

There have been many attempts to define animal welfare. According to the Farm Animal Welfare Committee (FAWC), welfare includes both physical and mental health and is determined by the skills of stockpeople, owners, and the farming system [34]. External factors, such as infectious disease epidemics, adverse weather conditions, global economics, and geo-political influences, can also impact animal welfare [34].

This growing interest in animal welfare, especially concerning husbandry and transport methods, has led to the possibility of using the claim "from certified herds" for herds that meet welfare requirements above the minimum standards established by law [35]. Thus, animal welfare would have an additional economic value, as it would offer consumers a product of higher quality and, at the same time, become an opportunity to increase farmers' income. However, some pain and distress are unavoidable in all animal sectors even with current knowledge, husbandry, and farming practices, although the goal should be to minimize their occurrence [34].

When assessing any welfare problem, consideration should be given to the extent of poor welfare, the intensity and duration of suffering, the number of animals involved, the alternatives available and the opportunities to promote well-being [34]. Moreover, animal welfare is pivotal to guaranteeing high hygiene, organoleptic standards, and production quality [18]. For this purpose, non-coercive and non-aggressive attitudes on the part of farm and slaughterhouse operators would be essential $[16,17]$.

\subsection{Indicators of Animal Welfare}

Animal welfare is defined as a permanent state reflecting an animal's subjective perception of its situation indicated by behavioural, postural, and physiological parameters [36]. Although the issue of animal welfare has been a source of concern in the scientific community and of attempts to build common protocols over the last decades, many aspects are still under debate, such as the validity and reliability of the welfare indicators chosen [36].

An indicator can be defined as "a thing that indicates the state or level of something" [37]. A potential animal welfare indicator must include the following principles: validity (i.e., be meaningful for animal welfare), reliability (i.e., produce consistent results 
when used by different observers) and feasibility (i.e., easy to use in the field) [38,39]. Resource- and management-based measures (RBMs and MBMs) are considered to be indirect indicators of animal welfare. On the other hand, direct indicators, or animal-based measures (ABMs), assess the animal's response to the resources available and to management practices [40]. The adoption of ABMs over non-ABMs is also encouraged by the European Food Safety Authority [41].

To evaluate an animal's welfare state accurately, it is thus essential to rely on multiple scientifically validated indicators, covering all the facets of welfare (behavioural, psychological, and physiological) and reflecting an individual's chronic state [42]. These indicators must be based on the characteristics and needs of the species and reflect the animal's perception [43]. Finally, when evaluating the welfare of a group of animals, the proportion of individuals presenting signals of poor welfare must be considered [44].

In Europe, the Welfare Quality ${ }^{\circledR}$ project [45] was one of the most important efforts for the development of on-farm welfare assessment protocols, using both $A B$ and non- $A B$ measures. The scores obtained are then organised to assess unit compliance with four main welfare principles (good feeding, good housing, good health, and appropriate behaviour). Finally, these scores are used to come to an overall evaluation.

There are two axes primarily involved in animal stress response: the sympathetic adrenal medullary system (SAM) and the hypothalamic-pituitary-adrenocortical axis (HPA) [46]. Activation of the sympathetic nervous system in emergencies involves the release of catecholamines (epinephrine and norepinephrine) from the adrenal medulla and of cortisol from the zona fasciculate of the adrenal cortex [47]. This mechanism is part of the endocrine response for self-protection of the body in the presence of a stressor [48].

Under normal physiological conditions, catecholamines are released from the adrenal medulla to maintain body homeostasis and to regulate several body functions including maintenance of blood pressure [49]. However, under stressful situations, high concentrations of catecholamines are discharged into the bloodstream in preparation for the possibility of rapid energy expenditure [49].

Cortisol plays a role in acute or chronic stress and is often called a stress hormone because its production increases during severe psychophysical stress conditions and therefore, it is an indicator of animal welfare [50]. Indeed, several studies have focused on measuring levels of cortisol or its metabolites in plasma, faeces, urine, saliva, and milk of different animal species [51,52]. Because salivary cortisol concentrations correlate well with cortisol concentrations in plasma [53], cortisol in saliva mirrors HPA axis activation. Plasma, salivary, faecal, and urine cortisol concentrations reflect acute stressors, but, unlike hair cortisol, they do not represent a long-term retrospective integrative stress response [54]. Indeed, hair cortisol concentrations can be used as a tool to assess chronic stress or long-term activity of the HPA but not for occasional and sporadic stress events [55].

The assessment of HPA axis activity has become a common approach to studying stress and animal welfare, along with measurements of other endpoints of the stress response [56]. Moreover, collecting blood at exsanguination is a common and non-invasive technique for assessing animals' physiological responses to the journey toward the slaughterhouse, to pre-slaughter handling as well as to slaughtering procedures. Indeed, among the parameters used as stress indicators, plasma cortisol is the most useful, showing a statistically significant variation $[57,58]$.

\subsection{Animal Welfare on the Farm}

Animals are sentient beings capable of experiencing both positive and negative emotions [59]. The animal welfare concept incorporates many animal-based factors, including health, the absence of stress and pain, the ability to perform innate behaviours, and affective state [60]. However, it is important to clarify that the absence of negative welfare indicators does not necessarily suggest optimal conditions of animal welfare [61] just as good management and environmental resources do not necessarily result in a high standard of welfare [62]. 
In fact, environmental aspects may show high variation from country to country due to different housing and management conditions, while individuals with different genetic backgrounds (e.g., different breeds) may respond differently to the same environment [41]. For this reason, current welfare assessment protocols highlight the importance and preference for animal-based indicators over resource- or management-based indicators for on-farm assessments [63].

In addition to conventional animal behaviour measures, many animal welfare protocols include a Qualitative Behavioural Assessment (QBA), i.e., a methodology involving the assessment of the animal's response to its environment $[59,64,65]$. Indeed, farm animal welfare assessment approaches are focused on animal-centred concepts that include the animals' needs [66], affective states [67] and inter-individual differences [68].

It is extremely important to understand the behaviour of livestock to avoid exposing them to poor welfare conditions, such as those induced by stressful management practices. Livestock housing conditions are often structurally simple and offer limited possibilities to exhibit species-appropriate behaviour $[69,70]$. These limitations can lead to frustration and abnormal behaviour, which are related to stress and reduced welfare [71]. To decrease these phenomena in livestock, a variety of new structures, items and challenges related to the animals' needs and natural behaviour must be provided [69]. Some of these changes include: (i) the gradual removal of practices of restraint and confinement [72], (ii) the banning of many forms of manipulation and mutilation [73], (iii) more sensitive management procedures, and (iv) the growing use of environmental enrichment to allow a higher degree of behavioural diversity [74].

Several studies [75-77] show that consumers strongly associate farm animal welfare with outdoor access, adequate space requirements and the ability of animals to express their natural innate behaviour. Others frequently cited criteria concerning nutrition, water supply and naturalness of feed. Meuwissen et al. [78] found that citizens consider space, medicines and living surface as the most important indicators of the level of animal welfare. For this reason, one of the key goals of new EU-funded projects is to develop a concept that adequately considers society's definition of animal welfare [79].

In 2008, the EU Welfare Quality project re-elaborated the concept of the "Five Freedoms" of animals [80] and defined four main areas of animal needs ("Welfare Principles"), which were then split into twelve independent criteria, each of which corresponded to a key welfare question [81,82]. The welfare principles and criteria are: Good feeding; Good housing; Good health; Appropriate behaviour.

Animal welfare science is improving our understanding of animals' needs and preferences and our awareness that their well-being could be compromised by management and husbandry practices [83]. In fact, a condition of poor animal welfare can also be caused by poor management by the farmer. A late or wrong diagnosis of a specific pathology arising on the farm inevitably affects animal well-being. Late intervention, incorrect diagnosis, and inappropriate treatments may lead to poor health and sufferance by patients, as shown in our work [84].

\subsection{Animal Protection during Transport}

Transport is always an essential and intrinsic part of livestock farming [34]. Today, animals are transported globally for the purposes of rearing, production, breeding, slaughter, or entertainment [34]. Live transport of cattle and sheep is increasing due to the growing demand for meat [85]. However, transport is a significant stressor for animals and frequently leads to severe behavioural and health problems [86,87]. Handling, loading/unloading, comingling, trailer accelerations and vibrations, exposure to new environments, and extreme temperatures during transport can cause stress [88,89]. Moreover, transport has been reported to affect the immune response, increasing susceptibility to different diseases $[90,91]$. 
Council Regulation (EC) No 1/2005 [92] regulates animal transport in Europe and contains special requirements for journeys exceeding eight hours, including maximum journey duration, stopping at control posts, and on-road inspections. Transported species have different physiological needs, according to the transport conditions, means of transport used, and climatic zones [93]. Consequently, Council Regulation (EC) No 1/2005 has special requirements for each species, in particular regarding vehicle design and maximum journey duration. In addition, regardless of journey duration, the position of the animals in the vehicle during transport can affect skin blemishes and meat quality [94].

For pigs, transport to the slaughterhouse is a stressor, affecting their health and welfare and, consequently, their carcass quality [95]. During transport, pigs are subjected to many adverse situations including weather conditions [96].

For cattle, loading and unloading are often more stressful than the journey itself [97,98]; however, there are no regulations that define the appropriate conditions or time limits for these procedures. This may be because they are typically short (normally taking less than $15 \mathrm{~min}$ ) or because there is no simple and non-invasive method for scoring the stress imposed by loading and unloading [99].

The transport of broilers is considered a critical point in the production chain [100], causing possible consequences on their welfare [101]. In fact, broilers are exposed to intense stressful conditions during transport from the farm to the slaughterhouse, and long-term deprivation of water and feed is linked to yield losses at slaughter [102]. In addition, changes in climatic conditions during transport (temperature, relative humidity and air flow) are important stressors for broilers [103] and are not fully controllable in the vehicles used for broiler transportation. Indeed, the microclimate of shipments can be influenced by climatic conditions during transport [104]. Therefore, transport distance and duration, as well as climatic conditions, can interfere with broiler welfare and behaviour [105] and, ultimately, with their performance [106,107].

Nevertheless, animal welfare during transport is difficult to measure and interpret [104]. For this reason, other measurements of animal welfare are needed, such as bruises on the carcass, which are considered important animal-based performance variables. The assessment of bruises can improve transport conditions and reduce economic losses [108].

European Regulations in the Field of Animal Transportation

There have been many different Community rules on animal transport over the years. The first to be issued was Directive 91/628/EEC relating to the protection of animals during transport and amending Directives 90/425/EEC and 91/496/EEC (the latter two Directives concern veterinary and zootechnical controls applicable to the trade in certain live animals and products of animal origin and to live animals originating from third countries being introduced into the Community). Subsequently, changes were made to Directive 91/628/EEC through Directive 95/29/EC and a series of regulations and decisions have been produced that concern particular areas, among which the most notable are:

- Council Regulation (EC) No 1255/97 of 25 June 1997 concerning Community criteria for staging points and amending the route plan referred to in the Annex to Directive 91/628/EEC;

- Council Regulation (EC) No 411/98 of 16 February 1998 on additional animal protection standards applicable to road vehicles used for the carriage of livestock on journeys exceeding eight hours;

- Commission Decision 2001/298/EC of 30 March 2001 amending the Annexes to Council Directives 64/432/EEC, 90/426/EEC, 91/68/EEC and 92/65/EEC and to Commission Decision 94/273/EC as regards the protection of animals during transport;

- Council Regulation (EC) No 1040/2003 of 11 June 2003 amending Regulation (EC) No 1255/97 as regards the use of staging points.

Following these rules, the Council of the European Union invited parties to submit proposals to ensure the effective implementation and strict enforcement of existing legisla- 
tion, improve the protection and welfare of animals, as well as to prevent the occurrence and spread of infectious animal diseases and put in place more stringent requirements to prevent pain and suffering in order to safeguard the welfare and health of animals during and after transport.

This invitation gave rise to the latest regulatory act relating to the transport of live vertebrate animals within the Community, namely Council Regulation (EC) No 1/2005 on the protection of animals during transport and related operations; this regulation, with effect from 5 January 2007, modified a series of previous Directives and Regulations and is still in place today.

The main innovations contained in Council Regulation (EC) No 1/2005 are: empowerment of operators such as keeper, transporter, drivers and guardians, for which legal obligations are clearly specified; identification of a transport manager; need for greater training of drivers, guardians and staff who look after the animals, with specific courses, examinations and issuance of a certificate of suitability essential for carrying out the activity; greater controls also based on the use of new technologies (satellite navigation systems); obligation to fill in the travel log for all long journeys (over $8 \mathrm{~h}$ in exchanges between member countries and $12 \mathrm{~h}$ for trips within national boundaries); more restrictive rules for authorizing transporters (traceability, emergency plans, training courses, etc.); greater regulation of what happens before and after transport (for example, in ports and slaughterhouses), with rules governing loading and unloading operations and the movement of animals; establishment for each Member State of a contact point through which to exchange information and mutual assistance in the field of application of the regulation; definitions of the infringement notification procedures between the competent authorities that issue the authorizations to transporters, the vehicle approval certificates or the certificates of competence of the personnel responsible for looking after animals.

The new regulation, consistent with the fundamental principle that animals must not be transported in conditions such as to expose them to unnecessary injury or suffering [109], applies to transport carried out in connection with trade in live vertebrate animals, whether that is for transport carried out for one's own account or for transport carried out on behalf of third parties. It was necessary in order as far as possible to limit long journeys, which are one of the major causes of stress for transported animals [86,87].

Council Regulation (EC) No 1/2005 involves not only transporters proper, but also breeders, traders, operators of collection centers, control posts and slaughterhouses as the loading and unloading of animals represent other important moments of transport-related stress.

The new provisions, however, do not apply to transport carried out by breeders of their animals with their own means of transport up to a maximum distance of $50 \mathrm{~km}$ or carried out for reasons of seasonal transhumance, just as they do not apply to persons carrying out animal transport for a maximum distance of $65 \mathrm{Km}$; this is, for example, clarified in Italy Ministry of Health memorandum No DGVAX/45209-Pi.6.bh/2 of 14 December 2006 as well as by the Provision of 20 March 2008-in the State-Regions Agreement-concerning "Initial provisions for authorizing the transport of live animals", published in the Italian Official Journal general series No 118 of 21 May 2008.

Council Regulation (EC) No 1/2005 also instructs Member States to autonomously establish rules on penalties applicable to infringements of the provisions of this Regulation and take all necessary measures to ensure that they are implemented. The penalties provided for must be effective, proportionate and dissuasive. Member States shall communicate these provisions to the Commission, as well as the provisions for the application of Article 26 and subsequent amendments thereto. In case of violations of the provisions of Council Regulation (EC) No 1/2005, the Italian Competent Authority will apply Legislative Decree No 151 of 25 July 2007 containing the sanctioning provisions regarding animal welfare during transport. 


\subsection{Animal Protection at the Time of Killing}

Slaughterhouses have the critical responsibility of ending the lives of animals to produce meat for human consumption while maintaining high standards of animal care [110]. To guarantee appropriate animal handling and management at slaughter plants, proper flooring must be available in animal handling areas, beginning on the trailer, and extending all the way through the restrainers and the lairage facilities [111]. Moreover, adequate training in slaughterhouse practices should be required to make sure that the slaughter procedures are carried out by people with an appropriate level of competence [112].

The protection of animals at the time of killing is regulated by Council Regulation (EC) No 1099/2009 of 24 September 2009 [113]. This regulation establishes that animals shall only be killed after stunning and the loss of consciousness and sensibility shall be maintained until their death. The stunning method plays a very important role throughout the whole production chain, from animal welfare to meat quality and public health [114]. However, the derogation from stunning is confirmed in case of religious slaughter taking place in slaughterhouses, leaving a certain level of discretion to each Member State. Although religious slaughter is considered a humane method, there are some animal welfare concerns related to the pain resulting from neck incision, distress during exsanguination, and the extended duration until loss of consciousness [115-117]. Stunning the animal before slaughter is mandatory in the European Union, USA, Australia, New Zealand, South Africa, Brazil, and East Asian Countries, but it is not permissible in many Muslim countries. Although there are exceptions, several stunning methods have been accepted by Malaysia, Indonesia, and some Muslim communities in the UK, Sweden, Germany, Norway, Switzerland, and Denmark, provided that the animal is stunned but alive until it is slaughtered [118]. There is no broad regulation in the EU on slaughter without stunning; individual countries decide for themselves. A total ban on ritual slaughter is applicable only in Sweden, while in Poland, Denmark, and Greece, it can only be performed after the animal has been previously stunned [118].

Some studies [58] have monitored animal stress during the slaughtering phases, trying to compare traditional procedures, which include stunning and religious procedures where stunning is not contemplated. The plasma cortisol measured for monitoring the stress of the animals showed greater variation between the two methods of slaughtering during the exsanguination phase. Therefore, cortisol plays a central role in the process of protein and fat degradation. Moreover, increased levels of cortisol, even in the late slaughtering phases, may alter the organoleptic characteristics of the meat, such as a considerable decrease in marbling fat, which negatively affects meat flavour and tenderness [119].

\subsection{Animal Welfare and Animal Health}

Acute stress caused on the farm often turns into chronic stress, because in nature the animal can avoid the source of stress, for example by running away. Conversely, production animals cannot remove stress, as environmental conditions persist [120].

Stressful conditions can cause harmful responses, such as the inability to produce effective responses to infections [121] or can make the animal more vulnerable to disease $[122,123]$ showing that the stress to which ruminants are subjected affects the performance and health of animals and how chronic stress can affect product quality, food processing efficiency and reproductive success.

High neonatal mortality rates in lambs, calves and piglets are often caused by hypothermia, maternal malnutrition, and by gastrointestinal and respiratory injury [124]. These diseases are related to (i) incorrect housing of animals, (ii) inadequate staff training, (iii) incorrect colostrum management and (iv) absence of a positive relationship between resting hours and production [125].

Stress and disease affect growth [126], reproduction [127] and production. Tremetsberger et al. [128] evaluated the association between animal welfare and health through the Welfare Quality ${ }^{\circledR}$ protocol before and one year after the introduction of improvement 
actions. The study showed that producers with a Welfare Quality score corresponding to "no disease" had higher technical efficiencies.

Furthermore, Chatterton et al. [129] showed that diseases on farms affected the environmental profile. Indeed, the disease with the greatest influence on the environmental performance of a cow was Johne's disease, with a $24 \%$ increase in the footprint; for Salmonella and BVD, an increase in emissions of $16-20 \%$ is estimated; hepatic fasciculation, IBR, lameness and mastitis have an impact of between 7 and $10 \%$. Less important effects are those estimated for calf diarrhoea and pneumonia. Chatterton et al. [129] also report the estimates for beef cows. A healthy farm should correspond to a footprint of $17.1 \mathrm{~kg}$ of $\mathrm{CO}_{2}$ eq. $/ 1 \mathrm{~kg}$ of meat; however, where diseases are present, the footprint is greater than $6.6 \%$.

Hospito and Sonesson [130] used the LCA methodology to assess the environmental performance of a reference farm compared to that of farming which, thanks to the adoption of appropriate measures, has a lower incidence of mastitis (15\% compared to at $18 \%$ ). The lower incidence of mastitis allows for better environmental performance, such as a reduction in the carbon footprint per kilogram of milk by $2.5 \%$ or the consumption of nonrenewable resources by $5.8 \%$. Mostert et al. [131] simulated the effect of clinical mastitis on the intensity of greenhouse gas emissions ( $\mathrm{kg}$ of $\mathrm{CO}_{2}$ eq. $/ \mathrm{kg}$ of milk); the disease is associated with an increase in the carbon footprint of $6.2 \%$, due to milk waste, reduction in production and prolonged calving interval. Another very frequent and economically relevant bovine disease is ketosis. Mostert et al. [132] studied the effects of its subclinical form on some environmental indicators. It was found that the emission intensity of greenhouse gases increases by $20.9 \mathrm{~kg} \mathrm{CO}$ eq. in the case of subclinical mastitis, due to the greater distance between birth and conception, the elimination of milk, the reduction in production and the greater number of culled animals.

At the farm level, we know that rational husbandry that allows for healthy, welldeveloped and fertile animals and that follows protocols of attention to animal welfare is one of the main strategies for reducing the environmental impact of livestock production [133].

\section{Antibiotics, Antimicrobial Resistance, and Animal Welfare}

Most of the literature on the consequences of the emergence and spread of antimicrobial resistance (AMR) among animals relates to the risks of transfer to people, and thereby a potential impact on public health. However, it must be considered that one of the reasons to use antibiotics is to treat animals suffering from bacterial infections, and AMR in animal pathogens can lead to therapy failure with a direct negative effect on animal health and welfare. This aspect has received little or no scientific attention, and the burden of AMR on animal health is poorly investigated [134]. By contrast, much emphasis has been given to the use of antibiotics in food-producing animals in the form of growth promoters (AGP) and the treatment of healthy animals for metaphylactic or prophylactic purposes (Table 1) [135].

Table 1. Non-therapeutic use of antimicrobials in food-producing animals.

\begin{tabular}{cccc}
\hline Terminology & Scope & Dosage & Current Legislation (EU) \\
\hline Antibiotic growth promoters & Increased growth of animals or feed efficiency & Sub-therapeutic & Total ban (since 2006) \\
\hline Metaphylaxis & $\begin{array}{c}\text { Control of a bacterial disease by treating } \\
\text { healthy animals during an outbreak }\end{array}$ & Therapeutic & Restrictions (starting from January 2022) \\
\hline Prophylaxis & $\begin{array}{c}\text { Administration to healthy animals to } \\
\text { prevent diseases during high-risk phases } \\
\text { of production }\end{array}$ & Therapeutic & Restrictions (starting from January 2022) \\
\hline
\end{tabular}

AGPs have been banned in the European Union since 2006 [136] and in the USA since 2017 [137]. Moreover, according to the Regulation of the European Parliament on veterinary medicinal products, as from January 2022, prophylaxis and metaphylaxis in Europe should be kept to a minimum and considered an exception rather than a rule [138].

An overall decrease of $34 \%$ in the global use of antimicrobials (AMU) in food-producing animals for the years between 2015 and 2017 is highlighted by the 5th OIE report on AMU in animals. The reduced AMU seems to be strictly related to the ban and the recommendations 
to avoid the use of AGPs. In fact, a total of 112 out of 170 countries enrolled in this report declared that they did not use AGPs, regardless of the presence of any regulations [139].

\section{From the Bans to the Good Practices: How to Minimize AMU}

The misuse of antibiotics in the past as AGPs contributed to the general perception that antibiotics are incorrectly used and/or they should not be used in food-producing animals at all. For instance, according to an interview by the Eurobarometer Agency in 2018, more than half of European citizens are not aware that AGPs have been banned in Europe since 2006, and a third of them think that sick animals should not be treated with antibiotics [140]. Those beliefs are in striking contrast with the rights of animals as living beings to be treated and their welfare. In addition, the goal of creating 'antibiotic-free' farms is achievable only in short-term production systems (such as the poultry meat industry). In a recent survey, farmers and vets declared that the switch to raising animals without antibiotics is due mainly to market pressures, and less commonly for health-related reasons, such as to reduce AMR or to improve animal health and welfare [141].

In general, it is imperative (i) to treat animals appropriately and when necessary, to ensure animal health, (ii) to implement alternatives to the use of antibiotics in major farm animals to curtail rising AMR and its impact on human morbidity and mortality. Some researchers suggest that a shift to less intensive rearing and increased attention to hygiene can resolve many of the situations where the disease and stress load on animals might warrant the use of antibiotics and augment the risk to human health [142,143]. To promote responsible AMU, international and national guidelines have been issued with the dual purpose of ensuring therapeutic efficacy and mitigating resistance [144].

Management strategies and preventive-medicine programs that can be used to reduce disease incidence and thus AMU in food-producing animals are as follows: (i) providing stringent controls on hygiene, population dynamics, feed quality, and environmental conditions to prevent or reduce stress; (ii) eradicating/controlling specific diseases; (iii) optimizing nutrition to enhance natural immunity as a preventive measure to lessen the consequences of abrupt changes in conditions for animals (for example, transport and overcrowding); (iv) breeding for genetically disease-resistant livestock [145].

The processes involved in disease eradication or control are often costly in the short run, but they can be economically justified in specific situations, generally when the public health risk is substantial. Moreover, the judicious use of antibiotics is related to documented diagnosis of the presence of a bacterial pathogen and the choice of the proper drug by means of in vitro susceptibility tests.

Alternative strategies such as vaccines and biosecurity must be exploited. Biosecurity may be defined as all measures taken to prevent both the introduction and the spread of infectious (and parasitic) agents on the farm. It can broadly be divided into "external" biosecurity, focused on preventing introduction of infectious agents, and "internal" biosecurity, focused on preventing their spread within an individual farm, and hopefully their further dissemination via farm waste [146]. Several authors have found an association between lower prevalence of respiratory infections in cattle and high biosecurity levels [147,148]. High standards of biosecurity play a pivotal role in programs for reducing AMU in pig and poultry farms [149]. Other authors have highlighted a statistically significant lower AMU with improved levels of welfare on beef farms in Italy [150]. Altogether, biosecurity and welfare practices are strictly related to each other and have to be improved, as they contribute, just as vaccination protocols do, to lowering the risk of disease and hence the need for AMU [149].

\section{Conclusions}

Humans are increasingly affecting the climate and the earth's temperature by burning fossil fuels, cutting down forests and farming livestock. This adds enormous amounts of greenhouse gases (carbon dioxide, methane and nitrous oxide) to those naturally occurring in the atmosphere, thus increasing the greenhouse effect and global warming [151]. 
Through this study, we attempted to clarify how the implementation of animal welfare standards can lead to a reduction in the use of antibiotics and a reduction in the environmental impact of intensive farms, whereas the current system of intensification of agriculture and livestock rearing would lead to an increase in greenhouse gas emissions of $77 \%$ by 2050 . These emissions could contribute to an increase in world temperature of close to $2{ }^{\circ} \mathrm{C}$ [152].

In this context, a new farm management system must be introduced, one that is more friendly to the environment through greater attention to animal welfare and the correct use of veterinary drugs. Animal production should not be dependent on antibiotic use. However, if animals get sick and treatment is indicated, antibiotics should continue to be given, compliant with responsible use. Such use should be in parallel with good management, good housing, appropriate nutrition for preventing enteric diseases and a high level of external and internal biosecurity on farms, to ensure that the infection pressure is kept at a minimum level. On the other hand, EU Regulation 2016/429 on transmissible animal diseases (Animal Health Law), explains that "animal health and welfare are linked: better animal health promotes better animal welfare, EU 2016/429 and vice versa" [153].

In Italy, the Ministry of Health, with the support of the National Reference Centre for Animal Welfare, has developed a protocol known as "Classyfarm" based (i) on the regulations in force concerning the protection of animals on farms, (ii) on the checklists already used for checks by public veterinary services and (iii) on the most recent studies available on the subject [154].

In this perspective, it seems clear that the effective application of animal welfare standards, as well as a better involvement of all actors in the livestock industry-including institutions-could lead to a new, and more sustainable, farming approach [155].

Author Contributions: Conceptualization, G.B., G.T. and F.E.C.; writing-original draft preparation, G.B., M.C., G.T. and F.E.C.; writing-review and editing, G.B., M.C., E.C., G.C., M.M.D., N.B., R.B. and F.E.C.; supervision, G.B., M.C. and F.E.C.; funding acquisition, G.B. All authors have read and agreed to the published version of the manuscript.

Funding: This research received no external funding.

Institutional Review Board Statement: Not applicable.

Informed Consent Statement: Not applicable.

Acknowledgments: The authors would like to thank Anthony Green for kindly reviewing the English in the manuscript.

Conflicts of Interest: The authors declare no conflict of interest.

\section{References}

1. Celentano, F.E. Il Sistema internazionale di contrasto al cambiamento climatico tra inefficacia e astrattezza. Il necessario coinvolgimento dei privati. Comunitàint 2020, 1, 44-73.

2. United Nations, Department of Economic and Social Affairs, Population Division. World population prospects: The 2017 Revision, Key Findings, and Advance Tables. UN Resolutions Database. Working Paper No. ESA/P/WP/248; Available online: http:/ / www.documents.un.org/ (accessed on 9 December 2021).

3. Grossi, G.; Goglio, P.; Vitali, A.; Williams, A. Livestock and climate change: Impact of livestock on climate and mitigation strategies. Anim. Front. 2018, 9, 69-76. [CrossRef]

4. World Society for the Protection of Animals. Livestock Production and Climate Change. Available online: https://unfccc.int/ (accessed on 9 December 2021).

5. Villani, U. Istituzioni di Diritto dell'Unione Europea, 3rd ed.; Cacucci: Bari, Italia, 2020; p. 468, ISBN 9788866118725.

6. European Commission. Consolidated Version of the Treaty on the Functioning of the European Union. Available online: https:/ / eur-lex.europa.eu/legal-content/EN/TXT/PDF/?uri=CELEX:12012E/TXT\&from=EN (accessed on 26 October 2012).

7. Food and Agriculture Organization. Livestock Long Shadow. Available online: http:/ /www.fao.org (accessed on 9 December 2021).

8. European Commission. Communication from the Commission to the European Parliament, the Council, the European Economic and Social Committee and the Committee of the Regions-New EU Forest Strategy for 2030. Available online: https: / / ec.europa. eu/info/sites /default/files/comunications-new-eu-forest-strategy-2030_with-annex_en.pdf (accessed on 9 December 2021).

9. Dokić, D.; Gavran, M.; Gregić, M.; Gantner, V. The impact of trade balance of agrifood products on the state's ability to withstand the crisis. HighTech Innov. J. 2020, 1, 107-111. [CrossRef] 
10. Hafez, H.M.; Attia, Y.A. Challenges to the Poultry Industry: Current Perspectives and Strategic Future after the COVID-19 Outbreak. Front. Vet. Sci. 2020, 7, 516. [CrossRef] [PubMed]

11. Churchward-Venne, T.A.; Pinckaers, P.J.; van Loon, J.J.; van Loon, L.J. Consideration of insects as a source of dietary protein for human consumption. Nutr. Rev. 2017, 75, 1035-1045. [CrossRef]

12. Hashem, N.M.; Hassanein, E.M.; Hocquette, J.-F.; Gonzalez-Bulnes, A.; Ahmed, F.A.; Attia, Y.A.; Asiry, K.A. Agro-Livestock Farming System Sustainability during the COVID-19 Era: A Cross-Sectional Study on the Role of Information and Communication Technologies. Sustainability 2021, 13, 6521. [CrossRef]

13. Barzanti, F. La tutela del benessere degli animali nel Trattato di Lisbona. Riv. Di Dirit. Agrar. 2013, 1, 49.

14. Celentano, F. L'ordinamento dell'Unione europea alla prova del diritto al benessere degli animali. In Scritti su Etica e Legislazione Medica e Veterinaria; Cacucci: Bari, Italy, 2017; pp. 27-40, ISBN 9788866116219.

15. Belk, K.E.; Scanga, J.A.; Smith, G.C.; Grandin, T. The Relationship between Good Handling/Stunning and Meat Quality in Beef, Pork, and Lamb. In Proceedings of the American Meat Institute Foundation, Animal Handling and Stunning Conference, Colorado State University, Fort Collins, Washington, DC, USA, 21-22 February 2002.

16. Faucitano, L. Pre-slaughter stressors effects on pork: A review. J. Muscle Foods 1998, 9, 293-303. [CrossRef]

17. Lensink, B.J.; Fernandez, X.; Cozzi, G.; Florand, L.; Veissier, I. The influence of farmers' behavior on calves' reactions to transport and quality of veal meat. J. Anim. Sci. 2001, 79, 642-652. [CrossRef]

18. Bozzo, G.; Di Pinto, A.; Bonerba, E.; Ceci, E.; Mottola, A.; Roma, R.; Capozza, P.; Samoilis, G.; Tantillo, G.; Celano, G.V. Kosher slaughter paradigms: Evaluation of slaughterhouse inspection procedures. Meat Sci. 2017, 128, 30-33. [CrossRef] [PubMed]

19. De Vries, M.; De Boer, I. Comparing environmental impacts for livestock products: A review of life cycle assessments. Livest. Sci. 2010, 128, 1-11. [CrossRef]

20. Shirsath, A.P.; Henchion, M.M. Bovine and ovine meat co-products valorisation opportunities: A systematic literature review. Trends Food Sci. Technol. 2021, 118, 57-70. [CrossRef]

21. Aguiari, P.; Iop, L.; Favaretto, F.; Fidalgo, C.M.L.; Naso, F.; Milan, G.; Vindigni, V.; Spina, M.; Bassetto, F.; Bagno, A.; et al. In vitro comparative assessment of decellularized bovine pericardial patches and commercial bioprosthetic heart valves. Biomed. Mater. 2017, 12, 015021. [CrossRef] [PubMed]

22. Andrén, A. Cheese-Rennets and Coagulants. In Encyclopedia of Dairy Sciences, 2nd ed.; McSweeney, P., Fuquay, J., Fox, P., Eds.; Academic Press: Cambridge, MA, USA, 2011; pp. 574-578, ISBN 9780123744029.

23. Molina-Moreno, V.; Leyva-Díaz, J.C.; Llorens-Montes, F.J.; Cortés-García, F.J. Design of Indicators of Circular Economy as Instruments for the Evaluation of Sustainability and Efficiency in Wastewater from Pig Farming Industry. Water 2017, 9, 653. [CrossRef]

24. Wentzel, S.; Schmidt, R.; Piepho, H.P.; Semmler-Busch, U.; Joergensen, R.G. Response of soil fertility indices to long-term application of biogas and raw slurry under organic farming. Appl. Soil Ecol. 2015, 96, 99-107. [CrossRef]

25. Ghisellini, P.; Protano, G.; Viglia, S.; Gaworski, M.; Setti, M.; Ulgiati, S. Integrated Agricultural and Dairy Production within a Circular Economy Framework. A Comparison of Italian and Polish Farming Systems. J. Environ. Account. Manag. 2014, 2, 372-391. [CrossRef]

26. Angenent, L.T.; Usack, J.G.; Xu, J.; Hafenbradl, D.; Posmanik, R.; Tester, J.W. Integrating electrochemical, biological, physical, and thermochemical process units to expand the applicability of anaerobic digestion. Bioresour. Technol. 2018, 247, 1085-1094. [CrossRef] [PubMed]

27. Fiorese, G.; Guariso, G.; Polimeni, A. Optimizing biogas production: An application to an Italian farming district. In Proceedings of the 4th International Congress on Environmental Modelling and Software (iEMSs 2008), Barcelona, Spain, 1 July 2008.

28. Nepstad, D.; McGrath, D.; Stickler, C.; Alencar, A.; Azevedo, A.; Swette, B.; Bezerra, T.; DiGiano, M.; Shimada, J.; da Motta, S.; et al. Slowing Amazon deforestation through public policy and interventions in beef and soy supply chains. Science 2014, 344, 1118-1123. [CrossRef] [PubMed]

29. De Vivo, R.; Zicarelli, L. Influence of carbon fixation on the mitigation of greenhouse gas emissions from livestock activities in Italy and the achievement of carbon neutrality. Transl. Anim. Sci. 2021, 5, txab042. [CrossRef]

30. Pinotti, L.; Luciano, A.; Ottoboni, L.; Manoni, M.; Ferrari, L.; Marchis, D.; Tretola, M. Recycling food leftovers in feed as opportunity to increase the sustainability of livestock production. J. Clean. Prod. 2021, 294, 126290. [CrossRef]

31. Luciano, A.; Tretola, M.; Ottoboni, M.; Baldi, A.; Cattaneo, D.; Pinotti, L. Potentials and Challenges of Former Food Products (Food Leftover) as Alternative Feed Ingredients. Animals 2020, 10, 125. [CrossRef]

32. Eckard, R.J.; Grainger, C.; de Klein, C.A. Options for the abatement of methane and nitrous oxide from ruminant production: A review. Livest. Sci. 2010, 130, 47-56. [CrossRef]

33. Gerber, P.J.; Steinfeld, H.; Henderson, B.; Mottet, A.; Opio, C.; Dijkman, J.; Falcucci, A.; Tempio, G. Tackling climate change through livestockA global assessment of emissions and mitigation opportunities. In Tackling Climate Change Through Livestock: A Global Assessment of Emissions and Mitigation Opportunities; Gerber, P.J., Steinfeld, H., Henderson, B., Mottet, A., Opio, C., Dijkman, J., Falcucci, A., Tempio, G., Eds.; Food and Agriculture Organization of the United Nations (FAO): Rome, Italia, 2013; ISBN 9789251079201.

34. Farm Animal Welfare Committee. Opinion on the Welfare of Animals during Transport. Available online: https://consult.defra.gov. uk/transforming-farm-animal-health-and-welfare-team/improvements-to-animal-welfare-in-transport/supporting_documents / fawcopiniononthewelfareofanimalsduringtransport.pdf (accessed on 9 December 2021).

35. European Commission. Attitudes of Europeans towards Animal Welfare. Available online: http:/ /ec.europa.eu/COMMFrontOffice/ publicopinion/index.cfm/Survey/getSurveyDetail/instruments/SPECIAL/surveyKy/2096 (accessed on 18 March 2016). 
36. Lesimple, C. Indicators of Horse Welfare: State of the Art. Animals 2020, 10, 294. [CrossRef] [PubMed]

37. Larousse. Le Grand Larousse Illustré 2018; 2018 Bicentenaire; Larousse: Paris, France, 2019; p. 2106.

38. Phythian, C.J.; Michalopoulou, E.; Jones, P.H.; Winter, C.J.; Clarkson, M.J.; Stubbings, L.A.; Grove-White, D.; Cripps, P.J.; Duncan, J.S. Validating indicators of sheep welfare through a consensus of expert opinion. Animal 2011, 5, 943-952. [CrossRef]

39. Rushen, J.; Chapinal, N.; de Passillé, A.M. Automated monitoring of behavioural based animal welfare indicators. Anim. Welf. 2012, 21, 339-350. [CrossRef]

40. Spigarelli, C.; Zuliani, A.; Battini, M.; Mattiello, S.; Bovolenta, S. Welfare Assessment on Pasture: A Review on Animal-Based Measures for Ruminants. Animals 2020, 10, 609. [CrossRef]

41. EFSA. Statement on the use of animal-based measures to assess the welfare of animals. EFSA J. 2012, 10, 2767. [CrossRef]

42. Sneddon, L.U.; Elwood, R.W.; Adamo, S.A.; Leach, M.C. Defining and assessing animal pain. Anim. Behav. 2014, 97, 201-212. [CrossRef]

43. Dawkins, M.S. Behavioural deprivation: A central problem in animal welfare. Appl. Anim. Behav. Sci. 1988, 20, 209-225. [CrossRef]

44. Hausberger, M.; Roche, H.; Henry, S.; Visser, E.K. A review of the human-horse relationship. Appl. Anim. Behav. Sci. 2008, 109, 1-24. [CrossRef]

45. Blokhuis, H.J. International cooperation in animal welfare: The Welfare Quality ${ }^{\circledR}$ project. Acta Vet. Scand. 2008, 50, 1-5. [CrossRef]

46. Schaefer, F.; Chen, Y.; Tsao, T.; Nouri, P.; Rabkin, R. Impaired JAK-STAT signal transduction contributes to growth hormone resistance in chronic uremia. J. Clin. Investig. 2001, 108, 467-475. [CrossRef] [PubMed]

47. Dallman, M.F.; Hellhammer, D. Regulation of the hypothalamo-pituitary-adrenal axis, chronic stress, and energy: The role of the brain networks. In The Handbook of Stress Science: Biology, Psychology, and Health; Contrada, R.J., Baum, A., Eds.; Springer: New York, NY, USA, 2011; pp. 11-36, ISBN 9780826114716.

48. Manteca, X. Conceptosgenerales de bienestaranimal. In Etología Veterinaria; Manteca, X., Ed.; Multimédica Ediciones Veterinarias: Barcelona, Spain, 2009; pp. 225-243, ISBN 9788496344280.

49. Shaw, F.; Tume, R. The assessment of pre-slaughter and slaughter treatments of livestock by measurement of plasma constituents-A review of recent work. Meat Sci. 1992, 32, 311-329. [CrossRef]

50. Stewart, M.; Webster, J.R.; Schaefer, A.L.; Cook, N.J.; Scott, S.L. Infrared thermography as a non-invasive tool to study animal welfare. Anim. Welf. 2005, 14, 319-325.

51. Pawluski, J.; Jego, P.; Henry, S.; Bruchet, A.; Palme, R.; Coste, C.; Hausberger, M. Low plasma cortisol and fecal cortisol metabolite measures as indicators of compromised welfare in domestic horses (Equus caballus). PLoS ONE 2017, 12, e0182257. [CrossRef]

52. Mercer-Bowyer, S.; Kersey, D.C.; Bertone, J.J. Use of fecal glucocorticoid and salivary cortisol concentrations as a measure of well-being of New York City carriage horses. J. Am. Vet. Med Assoc. 2017, 250, 316-321. [CrossRef]

53. Bohák, Z.; Szabó, F.; Beckers, J.F.; Melo de Sousa, N.; Kutasi, O.; Nagy, K.; Szenci, O. Monitoring the circadian rhythm of serum and salivary cortisol concentrations in the horse. Domest. Anim. Endocrinol. 2013, 45, 38-42. [CrossRef] [PubMed]

54. Heimbürge, S.; Kanitz, E.; Otten, W. The use of hair cortisol for the assessment of stress in animals. Gen. Comp. Endocrinol. 2019, 270, 10-17. [CrossRef] [PubMed]

55. Tallo-Parra, O.; Lopez-Bejar, M.; Carbajal, A.; Monclús, L.; Manteca, X.; Devant, M. Acute ACTH-induced elevations of circulating cortisol do not affect hair cortisol concentrations in calves. Gen. Comp. Endocrinol. 2017, 240, 138-142. [CrossRef] [PubMed]

56. Mac Dougall-Shackleton, S.A.; Bonier, F.; Romero, L.M.; Moore, I.T. Glucocorticoids and "Stress" Are Not Synonymous. Integr. Org. Biol. 2019, 1, obz017. [CrossRef]

57. Newman, D.; Young, J.M.; Carr, C.; Ryan, M.; Berg, E.P. Effect of Season, Transport Length, Deck Location, and Lairage Length on Pork Quality and Blood Cortisol Concentrations of Market Hogs. Animals 2014, 4, 627-642. [CrossRef] [PubMed]

58. Bozzo, G.; Barrasso, R.; Marchetti, P.; Roma, R.; Samoilis, G.; Tantillo, G.M.; Ceci, E. Analysis of Stress Indicators for Evaluation of Animal Welfare and Meat Quality in Traditional and Jewish Slaughtering. Animals 2018, 8, 43. [CrossRef] [PubMed]

59. Wemelsfelder, F.; Mullan, S. Applying ethological and health indicators to practical animal welfare assessment. Sci. Tech. Rev. Off. Int. Epizoot. 2014, 33, 111-120. [CrossRef] [PubMed]

60. Miele, M.; Veissier, I.; Evans, A.; Botreau, R. Animal welfare: Establishing a dialogue between science and society. Anim. Welf. 2011, 20, 103-117.

61. Napolitano, F.; Knierim, U.; Grass, F.; De Rosa, G. Positive indicators of cattle welfare and their applicability to on-farm protocols. J. Anim. Sci. 2009, 8, 355-365. [CrossRef]

62. Winckler, C. On-farm welfare assessment in cattle-From basic concepts to feasible assessment systems. In Proceedings of the XXIV World Buiatrics Congress, Nice, France, 15 October 2006; pp. 493-500.

63. De Vries, M.B.E.; Engel, B.; den Uijl, I.; van Schaik, G.; Dijkstra, T.; de Boer, I.J.M.; Bokkers, E.M. Assessment time of the welfare quality ${ }^{\circledR}$ protocol for dairy cattle. Anim. Welf. 2013, 22, 85-93. [CrossRef]

64. Keeling, L.; Evans, A.; Forkman, B.; Kjaernes, U. Welfare quality principles and criteria. In Improving Farm Animal Welfare, 1st ed.; Blokhuis, H.J., Miele, M., Veissier, I., Jones, B., Eds.; Wageningen Academic Publishers: Wageningen, The Netherlands, 2013; ISBN 9789086862160.

65. AWIN. Awin Welfare Assessment Protocol for Sheep. Available online: https://air.unimi.it/handle/2434/269114 (accessed on 20 August 2019).

66. Špinka, M. How important is natural behaviour in animal farming systems? Appl. Anim. Behav. Sci. 2006, 100, 117-128. [CrossRef] 
67. Mendl, M.; Burman, O.P.; Paul, E.S. An integrative and functional framework for the study of animal emotion and mood. Proc. R. Soc. B 2010, 277, 2895-2904. [CrossRef] [PubMed]

68. Forkman, B.; Furuhaug, I.L.; Jensen, P. Personality, coping patterns, and aggression in piglets. Appl. Anim. Behav. Sci. 1995, 45, 31-42. [CrossRef]

69. Newberry, R.C. Environmental enrichment: Increasing the biological relevance of captive environments. Appl. Anim. Behav. Sci. 1995, 44, 229-243. [CrossRef]

70. Averós, X.; Brossard, L.; Dourmad, J.Y.; de Greef, K.H.; Edge, H.L.; Edwards, S.A.; Meunier-Salaün, M.C. A meta-analysis of the combined effect of housing and environmental enrichment characteristics on the behaviour and performance of pigs. Appl. Anim. Behav. Sci. 2010, 127, 73-85. [CrossRef]

71. Mason, G.; Mendl, M. Why is there no simple way of measuring animal welfare? Anim. Welf. 1993, 2, 301-319.

72. Barnett, J.L.; Hemsworth, P.H.; Cronin, G.M.; Jongman, E.C.; Hutson, G.D. A review of the welfare issues for sows and piglets in relation to housing. Aust. J. Agric. Res. 2001, 52, 1-28. [CrossRef]

73. Menke, C.; Waiblinger, S.; Studnitz, M.; Bestman, M. Mutilations in Organic Animal Husbandry: Dilemmas' Involving Animals. In Animal Health and Welfare in Organic Agriculture; Vaarst, M., Roderick, S., Lund, V., Lockeretz, W., Eds.; CABI: Wallingford, UK, 2004; ISBN 978-0851996684.

74. Manteuffel, G.; Langbein, J.; Puppe, B. From operant learning to cognitive enrichment in farm animal housing: Bases and applicability. Anim. Welf. 2009, 18, 87-95.

75. De Greef, K.; Stafleu, F.; De Lauwere, C. A simple value-distinction approach aids transparency in farm animal welfare debates. J. Agric. Environ. Ethics 2006, 19, 57-66. [CrossRef]

76. Lassen, J.; Sandoe, P.; Forkman, B. Happy pigs are dirty! Conflicting perspectives on animal welfare. Livest. Sci. 2006, 103, 221-230. [CrossRef]

77. Marie, M. Ethics: The new challenge for animal agriculture. Livest. Sci. 2006, 103, 203-207. [CrossRef]

78. Meuwissen, M.M.; Van der Lans, I.A.; Huirne, R.B.M. A synthesis of consumer behaviour and chain design. In Dynamics in Chains and Networks, Sixth International Conference on Chain and Network Management in Agribusiness and the Food Industry; Wageningen Academic Publishers: Gelderland, The Netherlands, 2004; pp. 310-317, ISBN 978-90-76998-40-4.

79. Heise, H.; Theuvsen, L. Citizens' understanding of welfare of animals on the farm: An empirical study. J. Appl. Anim. Welf. Sci. 2017, 21, 153-169. [CrossRef] [PubMed]

80. Brambell, F. Report of the Technical Committee to Enquire into the Welfare of Animals Kept under Intensive Livestock Husbandry Systems; Command Report 2836; Her Majesty's Stationery Office: London, UK, 1965.

81. Blokhuis, H.J.; Veissier, I.; Miele, M.; Jones, B. The Welfare Quality ${ }^{\circledR}$ project and beyond: Safeguarding farm animal wellbeing. Acta Agric. Scand. Anim. Sci. 2010, 60, 129-140. [CrossRef]

82. Rushen, J.; Butterworth, A.; Swanson, J.C. Animal behavior and well-being symposium. Farm animal welfare assurance: Science and application. J. Anim. Sci. 2011, 89, 1219-1228. [CrossRef]

83. Royal College of Veterinary Surgeons and the British Veterinary Association. In Vet Futures Report; RCVS and BVA: London, UK, 2005.

84. Padalino, B.; Sandy, J.R.; Barrasso, R.; Trotta, A.; Bozzo, G.; Cafarchia, C. Rare Generalized Form of Fungal Dermatitis in a Horse: Case Report. Animals 2020, 10, 871. [CrossRef] [PubMed]

85. Carnovale, F.; Phillips, C.C. The Effects of Heat Stress on Sheep Welfare during Live Export Voyages from Australia to the Middle East. Animals 2020, 10, 694. [CrossRef] [PubMed]

86. Padalino, B. Effects of the different transport phases on equine health status, behavior, and welfare: A review. J. Vet. Behav. 2015, 10, 272-282. [CrossRef]

87. Šímová, V.; Večerek, V.; Passantino, A.; Voslárová, E. Pre-transport factors affecting the welfare of cattle during road transport for slaughter-A review. Acta Vet. Brno 2016, 85, 303-318. [CrossRef]

88. Schwartzkopf-Genswein, K.S.; Faucitano, L.; Dadgar, S.; Shand, P.; González, L.A.; Crowe, T.G. Road transport of cattle, swine and poultry in North America and its impact on animal welfare, carcass and meat quality: A review. Meat Sci. 2012, 92, 227-243. [CrossRef] [PubMed]

89. Tucker, C.B.; Coetzee, J.F.; Stookey, J.M.; Thomson, D.U.; Grandin, T.; Schwartzkopf-Genswein, K.S. Beef cattle welfare in the USA: Identification of priorities for future research. Anim. Health Res. Rev. 2015, 16, 107-124. [CrossRef] [PubMed]

90. Earley, B.; Sporer, K.B.; Gupta, S. Invited review: Relationship between cattle transport, immunity and respiratory disease. Animal 2017, 11, 486-492. [CrossRef] [PubMed]

91. Holman, D.B.; Timsit, E.; Amat, S.; Abbott, D.W.; Buret, A.G.; Alexander, T.W. The nasopharyngeal microbiota of beef cattle before and after transport to a feedlot. BMC Microbiol. 2017, 17, 70.

92. Council of European Union. Council Regulation (EC) 1/2005 of 22 December 2004 on the Protection of Animals during Transport and Related Operations and Amending Directives 64/432/EEC and 93/119/EC and Regulation (EC) No 1255/97. Available online: https: / / eur-lex.europa.eu/LexUriServ/LexUriServ.do?uri=CELEX:32005R0001:EN:HTML (accessed on 23 November 2007).

93. Marahrens, M.; Kleinschmidt, N.; Di Nardo, A.; Velarde, A.; Fuentes, C.; Truar, A.; Otero, J.L.; Di Fede, E.; Dalla Villa, P. Risk assessment in animal welfare-Especially referring to animal transport. Prev. Vet. Med. 2011, 102, 157-163. [CrossRef] [PubMed]

94. Arduini, A.; Redaelli, V.; Luzi, F.; Dall'Olio, S.; Pace, V.; Costa, L.N. Relationship between Deck Level, Body Surface Temperature and Carcass Damages in Italian Heavy Pigs after Short Journeys at Different Unloading Environmental Conditions. Animals 2017, 7, 10. [CrossRef] [PubMed]

95. Bench, C.; Schaefer, A.L.; Faucitano, L. The welfare of pigs during transport. In The Welfare of Pigs-From Birth to Slaughter; Faucitano, L., Schaefer, A.L., Eds.; Wageningen Academic Publishers: Wageningen, The Netherlands, 2008; pp. 161-195, ISBN 978-9086860661. 
96. Xiong, Y.; Green, A.R.; Gates, R. Characteristics of Trailer Thermal Environment during Commercial Swine Transport Managed under U.S. Industry Guidelines. Animals 2015, 5, 226-244. [CrossRef]

97. Agnes, F.; Sartorelli, P.; Abdi, B.H.; Locatelli, A. Effect of transport loading or noise on blood biochemical variables in calves. Am. J. Vet. Res. 1990, 51, 1679-1681.

98. Trunkfield, H.R.; Broom, D.M. The welfare of calves during handling and transport. Appl. Anim. Behav. Sci. 1990, 28, 135-152. [CrossRef]

99. María, G.A.; Villarroel, M.; Chacon, G.; Gebresenbet, G. Scoring system for evaluating the stress to cattle of commercial loading and unloading. Vet. Rec. 2004, 154, 818-821. [CrossRef] [PubMed]

100. Dam, A.; Fitzgerald, S. Poultry Handling and Transportation Manual. 2017. Available online: http:/ /www.poultryserviceassociation. com/uploads/2/7/9/6/27967763/2017_poultry_handling_and_transportation_manual.pdf (accessed on 9 December 2021).

101. Li, X.; Zito, S.; Sinclair, M.; Phillips, C.C. Perception of animal welfare issues during Chinese transport and slaughter of livestock by a sample of stakeholders in the industry. PLoS ONE 2018, 13, e0197028. [CrossRef]

102. Denadai, J.C.; Mendes, A.A.; Garcia, R.G.; Almeida, I.L.; Moreira, J.; Takita, T.S.; Pavan, A.C.; Garcia, E.A. Effect of feed and water withdrawal on carcass yield and breast meat quality of broilers. Braz. J Poult. Sci. 2002, 4, 101-109. [CrossRef]

103. Mitchell, M.A.; Kettlewell, P.J. Physiological stress and welfare of broiler chickens in transit: Solutions not problems! Poult. Sci. 1998, 77, 1803-1814. [CrossRef] [PubMed]

104. Dos Santos, V.M.; Dallago, B.L.; Racanicci, A.C.; Santana, Â.P.; Cue, R.I.; Bernal, F.M. Effect of transportation distances, seasons and crate microclimate on broiler chicken production losses. PLoS ONE 2020, 15, e0232004. [CrossRef] [PubMed]

105. Ulupi, N.; Aryani, S.S.; Evni, F.T.; Nugraha, R. Effects of transportation duration on broiler chicken physiology and performance factors. Int. J. Poult. Sci. 2018, 17, 197-204. [CrossRef]

106. Arikan, M.S.; Akin, A.C.; Akcay, A.; Aral, Y.; Sariozkan, S.; Cevrimli, M.B.; Polat, M. Effects of Transportation Distance, Slaughter Age, and Seasonal Factors on Total Losses in Broiler Chickens. Rev. Bras. Ciênc. Avíc. 2017, 19, 421-427. [CrossRef]

107. Vecerek, V.; Voslarova, E.; Conte, F.; Vecerkova, L.; Bedanova, I. Negative trends in transport-related mortality rates in broiler chickens. Asian-Australas. J. Anim. Sci. 2016, 29, 1796-1804. [CrossRef]

108. Huertas, S.M.; Kempener, R.; van Eerdenburg, F. Relationship between methods of loading and unloading, carcass bruising, and animal welfare in the transportation of extensively reared beef cattle. Animals 2018, 8, 119. [CrossRef]

109. Council of European Union. Council Resolution of 19 June 2001 on the Protection of Animals during Transport. Available online: https:/ / eur-lex.europa.eu/legal-content/EN/TXT/?uri=CELEX\%3A32001G0928\%2801\%29 (accessed on 28 September 2001).

110. Edwards-Callaway, L.N.; Calvo-Lorenzo, M.S. Animal welfare in the U.S. slaughter industry-a focus on fed cattle. J. Anim. Sci. 2020, 98, skaa040. [CrossRef]

111. North American Meat Institute. Recommended Animal Handling Guidelines and Audit Guide. Available online: http:// animalhandling.org/producers/guidelines_audits (accessed on 9 December 2021).

112. Dal Bosco, A.; Castellini, C.; Bernardini, M. Effect of transportation and stunning method on some characteristics of rabbit carcasses and meat. World Rabbit. Sci. 2010, 5, 115-119. [CrossRef]

113. Council of European Union. Council Regulation 1099/2009 of 24 September 2009 on the Protection of Animals at the Time of Killing. Available online: https:/ / eur-lex.europa.eu/legal-content/EN/TXT/?uri=celex:32009R1099 (accessed on 18 November 2009).

114. Ariño, B.; Hernández, P.; Blasco, A. Comparison of texture and biochemical characteristics of three rabbit lines selected for litter size or growth rate. Meat Sci. 2006, 73, 687-692. [CrossRef]

115. Gregory, N.G.; Fielding, H.R.; von Wenzlawowicz, M.; von Holleben, K. Time to collapse following slaughter without stunning in cattle. Meat Sci. 2010, 85, 66-69. [CrossRef] [PubMed]

116. Velarde, A.; Rodriguez, P.; Dalmau, A.; Fuentes, C.; Llonch, P.; von Holleben, K.V.; Anil, M.H.; Lambooij, J.B.; Pleiter, H.; Yesildere, T.; et al. Religious slaughter: Evaluation of current practices in selected countries. Meat Sci. 2014, 96, $278-287$. [CrossRef]

117. Zulkifli, I.; Goh, Y.M.; Norbaiyah, B.; Sazili, A.Q.; Lotfi, M.; Soleimani, A.F.; Small, A.H. Changes in blood parameters and electroencephalogram of cattle as affected by different stunning and slaughter methods in cattle. Anim. Prod. Sci. 2014, 54, 187-193. [CrossRef]

118. Salamano, G.; Cuccurese, A.; Sechi, P.; Cenci-Goga, B.T.; Poeta, A.; Cambiotti, V.; Santella, E. Acceptability of Electrical Stunning and Post-Cut Stunning Among Muslim Communities: A Possible Dialogue. Soc. Anim. 2013, 21, 443-458. [CrossRef]

119. Gregory, N.G. Animal Welfare and Meat Science; CABI: Wallingford, UK, 1998; Chapter 4; pp. 64-92, ISBN 085199296 X.

120. Broom, D.M. Animal welfare defined in terms of attempts to cope with the environment. Acta Agric. Scand. Sec. A Anim. Sci. 1996, 27, 22-28.

121. Sapolsky, R.M.; Romero, L.M.; Munck, A.U. How to glucocorticoids influence stress responses? Integrating permissive, suppressive, stimulatory, and preparative actions. Endocr. Rev. 2000, 21, 55-89. [CrossRef]

122. Gomes, A.S.; Quinteiro-Filho, W.M.; Ribeiro, A.; Ferraz-de-Paula, V.; Pinheiro, M.L.; Baskeville, E.; Akamine, A.T.; Astolfi-Ferreira, A.P.; Palermo-Neto, J. Overcrowding stress decreases 14 macrophage activity and increases Salmonella enteritidis invasion in broiler chickens. Avian Pathol. 2014, 43, 82-90. [CrossRef] [PubMed] 
123. Pulina, G.; Francesconi, A.D.; Stefanon, B.; Sevi, A.; Calamari, L.; Lacetera, N.; Dell'Orto, V.; Pilla, F.; Ajmone Marsan, P.; Mele, M.; et al. Sustainable ruminant production to help feed the planet. Ital. J. Anim. Sci. 2017, 16, 140-171. [CrossRef]

124. Windeyer, M.C.; Leslie, K.E.; Godden, S.M.; Hodgins, D.C.; Lissemore, K.D.; LeBlanc, S.J. Factors associated with morbidity, mortality, and growth of dairy heifer calves up to 3 months of age. Prev. Vet. Med. 2014, 113, 231-240. [CrossRef] [PubMed]

125. Bach, A.; Valls, N.; Solans, A.; Torrent, T. Associations between nondietary factors and dairy herd performance. J. Dairy Sci. 2018, 91, 3259-3267. [CrossRef]

126. Holland, B.P.; Burciaga-Robles, L.O.; VanOverbeke, D.L.; Shook, J.N.; Step, D.L.; Richards, C.J.; Krehbiel, C.R. Effect of bovine respiratory disease during preconditioning on subsequent feedlot performance, carcass characteristics, and beef attributes. J. Anim. Sci. 2010, 88, 2486-2499. [CrossRef] [PubMed]

127. Dobson, H.; Smith, R.F. What is stress, and how does it affect reproduction? Anim. Rep. Sci. 2000, 60, 743-752. [CrossRef]

128. Tremetsbergr, L.; Winckler, C.; Kantehardt, J. Animal health and welfare state and technical efficiency of dairy farms: Possible synergies. Anim. Welf. 2019, 28, 345-352. [CrossRef]

129. Chatterton, J.; Williams, A.; Hateley, G.; Curwen, A.; Elliott, J. A systems-LCA approach to modelling the impact of improvements in cattle health on greenhouse gas emissions. In Proceedings of the 9th International Conference on Agrifood Security, San Francisco, CA, USA, 8-10 October 2014.

130. Hospito, A.; Sonnesson, U. The environmental impact of mastitis: A case study of dairy herds. Sci. Tot Environ. 2005, 343, 71-82. [CrossRef]

131. Mostert, P.F.; Bokkers, E.A.; de Boer, I.M.; van Middelaar, C.E. Estimating the impact pf clinical mastitis in dairy cows on greenhouse gas emissions using a dynamic sthocastic simulation model: A case study. Animal 2019, 13, 2913-2961. [CrossRef] [PubMed]

132. Mostert, P.F.; van Middelaar, C.E.; Bokkers, E.M.; de Boer, I.M. The impact of subclinical ketosis in dairy cows on greenhouse gas emissions of milk production. J. Clean. Prod. 2018, 171, 773-782. [CrossRef]

133. Hristov, A.N.; Oh, J.; Lee, C.; Meinen, R.; Montes, F.; Ott, T.; Firkins, J.; Rotz, A.; Dell, C.; Adesogan, A.; et al. Mitigation of Greenhouse Gas Emissions in Livestock Production-A Review of Technical Options for Non-CO ${ }_{2}$ Emissions; FAO: Rome, Italy, 2013; pp. 274-284, ISBN 9789251076583.

134. Bengtsson, B.; Christina Greko, C. Antibiotic resistance-consequences for animal health, welfare, and food production. Ups. J. Med. Sci. 2014, 119, 96-102. [CrossRef]

135. Baptiste, K.E.; Kyvsgaard, N.C. Do antimicrobial mass medications work? A systematic review and meta-analysis of randomised clinical trials investigating antimicrobial prophylaxis or metaphylaxis against naturally occurring bovine respiratory disease. Pathog. Dis. 2017, 75. [CrossRef] [PubMed]

136. Council of European Union. Council Regulation 1831/2003 of 22 September 2003 on Additives for Use in Animal Nutrition. Available online: https:/ / eur-lex.europa.eu/legal-content/EN/TXT/?uri=CELEX\%3A32003R1831 (accessed on 18 October 2003).

137. Sneeringer, S.; Maria Bowman, M.; Matthew Clancy, M. The U.S. and EU Animal Pharmaceutical Industries in the Age of Antibiotic Resistance. Dep. Agric. Econ. Res. Serv. 2019, 264-280. [CrossRef]

138. Council of European Union. Council Regulation 2019/6 of 11 December 2018 on Veterinary Medicinal Products and Repealing Directive 2001/82/EC. Available online: https:/ / eur-lex.europa.eu/legal-content/en/ALL/?uri=CELEX:32019R0006 (accessed on 27 January 2019).

139. World Organisation for Animal Health. OIE Annual Report on Antimicrobial Agents Intended for Use in Animals. Available online: https: / / www.oie.int/app/uploads/2021/05/a-fifth-annual-report-amr.pdf (accessed on 9 December 2021).

140. European Commission Special Eurobarometer 478. Antimicrobial Resistance Report. 2018. Available online: https://www. eusaferhealthcare.eu/wp-content/uploads/ebs_478_en-1-min.pdf (accessed on 9 December 2021).

141. Singer, R.S.; Porter, L.J.; Thomson, D.U.; Gage, M.; Beaudoin, A.; Wishnie, J.K. Raising Animals Without Antibiotics: U.S. Producer and Veterinarian Experiences and Opinions. Front. Vet. Sci. 2019, 6, 452. [CrossRef] [PubMed]

142. World Health Organization. The Medical Impact of the Use of Antimicrobials in Food Animals. 1997. Available online: https: / / apps.who.int/iris/handle/10665/64439 (accessed on 9 December 2021).

143. Witte, W. Medical consequences of antibiotic use in agriculture. Science 1998, 279, 949-1096. [CrossRef] [PubMed]

144. Jensen, V.F. Promoting prudent antimicrobial use in the veterinary field. Vet. Rec. 2013, 16, 473-474. [CrossRef] [PubMed]

145. Axford, R.E.; Owen, J.B. Strategies for disease control. In Breeding for Disease Resistance in Farm Animals, 3rd ed.; Owen, J.B., Ed.; CAB International Redwood Press: Wales, UK, 2010; pp. 3-9, ISBN 9781845935559.

146. Dewulf, J. An online risk-based biosecurity scoring system for pig farms. Vet. Irel. J. 2014, 4, 426-429.

147. Ohlson, A.; Heuer, C.; Lockart, C.; Tråvén, M.; Emanuelson, U.; Alenius, S. Risk factors for seropositivity to bovine coronavirus and bovine respiratory syncytial virus in dairy herds. Vet. Rec. 2010, 167, 201-207. [CrossRef] [PubMed]

148. Stokstad, M.; Klem, T.B.; Myrmel, M.; Oma, V.S.; Toftaker, I.; Østerås, O.; Nødtvedt, A. Using Biosecurity Measures to Combat Respiratory Disease in Cattle: The Norwegian Control Program for Bovine RespiratorySyncytial Virus and Bovine Coronavirus. Front. Vet. Sci. 2020, 7, 167. [CrossRef] [PubMed]

149. Caekebeke, N.; Jonquiere, F.J.; Ringenier, M.; Tobias, T.J.; Postma, M.; van den Hoogen, A.; Houben, M.M.; Velkers, F.C.; Sleeckx, N.; Stegeman, J.A.; et al. Comparing Farm Biosecurity and Antimicrobial Use inHigh-Antimicrobial-Consuming Broilerand Pig Farms in the Belgian-Dutch Border Region. Front. Vet. Sci. 2020, 7, 558455. [CrossRef] 
150. Diana, A.; Lorenzi, V.; Penasa, M.; Magni, E.; Alborali, G.; Bertocchi, L.; De Marchi, M. Effect of welfare standards and biosecurity practices on antimicrobial use in beef cattle. Sci. Rep. 2020, 10, 1-13. [CrossRef] [PubMed]

151. Council of European Union. Climate Strategies and Targets. Available online: http:/ / ec.europa.eu/clima/policies/roadmap/ index_en.htm (accessed on 14 July 2021).

152. Bajzelj, B.; Richards, K.S.; Allwood, J.M.; Smith, P.; Dennis, J.S.; Curmi, E.; Gilligan, C.A. Importance of food-demand management for climate mitigation. Nat. Clim. Chang. 2014, 4, 924-929. [CrossRef]

153. Council of European Union. Council Regulation 2016/429 of 9 March 2016 on Transmissible Animal Diseases and Amending and Repealing Certain Acts in the Area of Animal Health. Available online: https://eur-lex.europa.eu/legal-content/EN/TXT/?uri= celex\%3A32016R0429 (accessed on 24 April 2021).

154. Bertocchi, L.; Fusi, F.; Angelucci, A.; Bolzoni, L.; Pongolini, S.; Strano, R.M.; Ginestreti, J.; Riuzzi, G.; Moroni, P.; Lorenzi, V. Characterization of hazards, welfare promoters and animal-based measures for the welfare assessment of dairy cows: Elicitation of expert opinion. Prev. Vet. Med. 2018, 150, 8-18. [CrossRef] [PubMed]

155. United Nations. Call for "Decisive Action Now" to Avoid Climate Catastrophe. Available online: https://news.un.org/en/ story/2021/09/1100382 (accessed on 20 September 2021). 